\title{
Clinical Mastitis in Sheep Smallholder System in Sharkia Province: Bacteriological Studies, In Vitro Antibiogram Profile and Mineral Picture
}

\author{
Hend M. El Damaty and ElShaima M. Fawzi \\ ${ }^{1}$ Department of Animal Medicine, Faculty of Veterinary Medicine, Zagazig University, 44511-Zagazig, Sharkia, Egypt.
}

Correspondence Author: Hend El Damaty, Department of Animal Medicine, Faculty of Veterinary Medicine, Zagazig University, 44511-Zagazig, Sharkia, Egypt.

E-mail: hendvet11@yahoo.com; Mobile: +2-01011458060

Received date: 23 February 2018, Accepted date: 23 April 2018, Online date: 28 April 2018

Copyright: (C) 2018 Hend M. El Damaty and ElShaima M. Fawzi. This is an open-access article distributed under the terms of the Creative Commons Attribution License, which permits unrestricted use, distribution, and reproduction in any medium, provided the original author and source are credited.

\begin{abstract}
Mastitis is one amongst the foremost common health issues that have economically influence on sheep production in Egypt. Intramammary infections (IMIs) of dairy ewes with bacterial pathogens represent as one of the most important causes of the ewes milk-drop syndrome. Failures of treatment the clinical cases are attributed mostly to the antimicrobial resistance of these pathogens. This study is performed to throw the light about the major bacterial pathogens implicated as reasons for clinical mastitis in ewes. Further, in vitro antibiogram profile of the identified pathogens was set up, additionally, measurement of minerals thought to be disturbed during clinical mastitis. Herein eighty hand milked clinically mastitic lactating ewes from different villages in Sharkia province, Egypt, were clinically and bacteriologically studied during the period from March till the end of December 2017. Fourteen distinctive antibiotics were used to assess the sensitivity and resistance pattern of each isolate. Out of the 160 udder halves that subjected to bacteriological culture, 15 halves were bacteriologically negative and the most frequent isolates had been obtained from 145 halves were Staphylococcus aureus (S.aureus) (47.5\%), Coagulase-negative staphylococci (CoNS) (13.7\%), E.coli (11.9\%), Corynebacterium spp. (8.1\%), Streptococcus agalactiae (Str. agalactiae) (6.9\%) and Str. uberis (2.5\%). Most gross changes of clinically examined mastitic ewes vary from hotness and swelling in acute cases to induration and fibrosis of one or more halves in chronic cases with $8.7 \%$ of the clinically affected glands were reach to the gangrenous stage. Statistically, there are significant variations between antibiotics treatment at $(\mathrm{P} \leq 0.05)$. Significantly decreased of serum calcium, sodium, chloride, potassium and phosphorus levels in clinically mastitic ewes in comparison with apparently healthy ewes either with or without a history of recent lambing except for calcium was decline in level in apparently normal recently lambing ewes but not significantly. On other hand, magnesium and zinc were not correlated with clinical mastitis in ewes in this study. From this investigation, we concluded that S.aureus implicated as a most causative agent of clinical ovine mastitis. A high sensitivity of gentamicin (98.94\%) followed by ciprofloxacin (91.85\%) as effective drugs for used in treatment trials to most of the isolated bacterial strains in this study and also recommended to constrain the use of penicillin in the future due to high resistance (87.38\%) recorded against it. Furthermore, the supplementation of these elements (calcium, sodium, chloride, potassium and phosphorus) to the ration may decrease the incidence of mastitis or using these elements along with specific drugs may be helpful in rapid restore of normal udder condition and milk balance.
\end{abstract}

Key words: Clinical mastitis, Ewes, Staphylococcus aureus, In Vitro Antibiogram, Gentamicin, Penicillin,Minerals.

\section{INTRODUCTION}

Sheep and goat production assumes a very important role as an income generating activity, significantly for the smallholders whereas being a source of animal protein to assist the national program [56]. Mastitis is still represented as one of the serious problems not only for dairy cows but also for dairy ewes [9, 33, 13]. Mastitis has seriously economic affecting sheep welfare by influence in both sheep production and management systems with serious financial outcomes [19]. Clinical mastitis is characterized by the udder and milk visible changes. It might be peracute, acute or chronic in nature. The clinical signs might be localized to the udder, or may include systemic changes that have a major impact on the economy of sheep production. Economic losses in terms of tremendous losses of milk yield, deteriorated milk quality, treatment cost, mortality of lambs and culling of ewes because of permanent mammary gland infection and in very severe cases, gangrene could develop within the mammary gland and the ewe would possibly die [16]. The etiology of ovine mastitis is thought to be caused by different pathogens including bacteria, fungi, and virus in spite of the bacterial infection is incriminated as the most predominant one [10].Coagulase-negative staphylococci and S.aureus respectively are incriminated widely to be the cause of subclinical and clinical IMIs [17]. Streptococcus spp., E. coli, Arcanobacterium pyogenes, Pseudomonas species, Pasteurella multocida and Clostridium perfringens type A are associated with clinical mastitis [11,7]. In last decades, more attention was paid to $S$. aureus as a predominant cause of both acute gangrenous mastitis and subclinical mastitis [16]. Coagulase-negative staphylococci are considered as one of the vital contributors in clinical mastitis in sheep with major importance in subclinical mastitic cases in ewes in contrast to dairy cows [37,29,31].Clinically ovine mastitis is characterized by rapid damage to the gland with histological lesions are evident within 2 days post infection so that rapid treatment especially 
Citation: Hend M. El Damaty and ElShaima M. Fawzi, 2018. Clinical Mastitis in Sheep Smallholder System in Sharkia Province: Bacteriological Studies, In Vitro Antibiogram Profile and Mineral Picture. Advances in Environmental Biology., 12(4): 6-11.

with most active antibiotics is required [25].In Egypt, sheep are mostly kept as a source of milk and meat production and to lesser extent to nursing of newly born lambs thus more attention needs to pay to the quick and correct identification of clinical mastitis and to the causes which influence milk yields as the use of dry period treatment to limit the proportion of the appearance week lambs or even death [30,54]. IMIs has an obvious financial importance in dairy flocks, it is one of the primary causes of the ewes milk-drop syndrome [28]. Minerals balance of milk is one of the essential requirement to ensure adequate feeding of neonates in addition to detection of some minerals as calcium, magnesium, sodium, chloride is important to evaluate the degree of abnormalities of udder tissue and a good indicator of udder infection [21]. In Egypt ewes, clinical mastitis got little consideration and only a few reports were conducted to describe it. Consequently, the objectives of this study were to throw the light about the major bacterial pathogens implicated as reasons for clinical mastitis in ewes raised under traditional house owners system in Sharkia province, to demonstrated in vitro antibiogram profile concerned with the identified organisms for near future its correct application to limit the incidence of the disease and to investigate the electrolytes imbalance as a factor aids in the occurrence of mastitis or may be as a result of occurrence of clinical mastitis including calcium, phosphorus, magnesium, sodium, chloride and zinc.

\section{MATERIALS AND METHODS}

\section{Clinical cases description:}

Ewes admitted to this study on the basis of belonging to smallholders production system, complain with a decline in the level of milk production and history of lambing since few weeks. Eighty lactating ewes were subjected to study during the period from March 2017 till the end of December 2017 from several localities in Sharkia province, Egypt. Each ewe underwent a clinical examination after compiling the case history for the presence or absence of any systemic reaction include toxemia, pyrexia, depression, anorexia, lameness, recumbency and even death in severe cases [26]. The physical inspection revealed changes in size, shape, and colour of the affected halves that appeared swollen, redness and painfully reacted by manual palpation. Abnormal colour and appearance of milk sometimes contain flakes and/or blood. Acute clinical mastitis mostly follows by gangrenous udder when badly neglected that is characterized by necrosis and a bruised udder.

\section{Milk sampling:}

A total of 160 milk samples were collected from 80 clinically mastitic ewes. Aseptic technique was applied in all steps of milk sampling as mentioned by [47]. Each milk sample labeled with identifier number, the samples were transported to the laboratory of Animal Medicine Department, Faculty of Veterinary Medicine, Zagazig University, Egypt in a cool box with a minimum delay.

\section{Culturing:}

The clinically mastitic milk samples were aerobically incubated for $24 \mathrm{~h}$ at $37{ }^{\circ} \mathrm{C}$ and then centrifuged for 20 minutes at $3000 \mathrm{rpm}$. The sediment was streaked on 5\% sheep blood agar after discarding the supernatant for presumptive isolation of bacteria. Isolation of studied bacteria was done on specific media for each. All plates were incubated at $37^{\circ} \mathrm{C}$ under aerobic condition and examined for the colonies growth after $24-48$ hours. The microorganisms were identified in accordance with [49].

\section{In Vitro Antibiogram}

The disc diffusion susceptibility test for each isolated bacteria was performed according to [24]. The following antimicrobial discs were tested (Oxoid, UK): ampicillin $(10 \mu \mathrm{g} /$ disk $)$, chloramphenicol (30 $\mu \mathrm{g} /$ disk), erythromycin $(15 \mu \mathrm{g} /$ disk), gentamicin $(10 \mu \mathrm{g} /$ disk), penicillin G (10 IU/disk), oxytetracycline (30

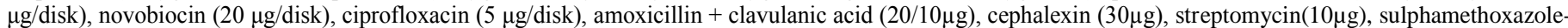
trimethoprim $(23.75 / 1.25 \mu \mathrm{g})$, neomycin $(30 \mu \mathrm{g})$, and kanamycin $(30 \mu \mathrm{g})$. The inhibition zone diameter for every disc was measured and therefore the isolates were categorized as sensitive or resistant primarily based upon the interpretative criteria developed by [15].

\section{Minerals measurement:}

Sixty blood samples, 20 samples from clinically mastitic ewes, (20 samples from apparently healthy ewes but with history of recent lambing from few weeks and 20 control samples from ewes apparently healthy without history of recent lambing and these ewes have bacteriologically negative milk samples ) were collected from jugular vein into vacutainer tubes without anticoagulant and left to clot. Centrifugation at $3000 \mathrm{rpm}$ for 15 minutes for separation of serum and picked up using sterile Pasteur pipettes, transferred to sterile labeled Eppendorf tubes. Serum minerals include calcium, magnesium, sodium, potassium, phosphorus, chloride and zinc were measured using commercial kits according to manufacture instructions.

\section{Statistical analysis:}

Antibiotics and minerals profile analysis of variance were done using SPSS V.13 software (SPSS, IL, USA). The differences among the means were determined using Duncan comparison test, where $\mathrm{P} \leq 0.05$ was considered significant.

\section{RESULTS}

Clinical mastitis diagnosis is straightforward, relies on the findings of the clinical examination. Eighty lactating ewes showed signs of clinical mastitis with various forms associated with or without systemic reactions. Gangrene was present in 14 halves $(8.7 \%)$ of the clinically affected glands, which characterized by a change in colour of udder skin varies from blue to black (Fig. 1-A, B). Forty-five halves had acute mastitis (Fig. 1-C, D) some of them have blood-tinged milk with signs of inflammation in the affected halves and other suffered from abscessed secreted milk which appear as thick, fetid, greenish fluid. Fibrosis of the udder was detected in 23 halves with the secretion of purulent to cheesy malodorous milk containing pus and 78 halves had milk mixed with flakes of coagulated materials or watery milk without signs of inflammation. Bacteriological examination of milk samples remains the 'gold standard' for etiological diagnosis of mastitis. Isolation and identification of major udder pathogens from 160 clinically mastitic halves belonging to 80 ewes revealed that $104(65 \%)$ and $41(25.6 \%)$ positive with single and mixed infection respectively (Table 1). 15 halves (9.4\%) were bacteriologically negative and the most frequent isolates had been obtained from 145 halves were $S$. aureus, in 76 samples (47.5\%) while CoNS recorded in 22 samples (13.7\%). Meanwhile, IMIs with $E$. coli were recorded in 19 samples (11.9\%), Corynebacterium spp. was isolated from 13 samples (8.1\%). 11 samples were recorded to have Str. agalactiae (6.9\%) and Str. uberis was isolated only from 4 samples (2.5\%). The most implicated pathogen in all infected halves was S. aureus either alone or mixed with other pathogens.

Since the primary approach for mastitis control in lactating and dry ewes is antimicrobial therapy, Antibiogram analysis of common isolates against 14 unique antimicrobial disks displayed variable antimicrobial susceptibility patterns (Tables $2 \& 3$ ). S.aureus was highly sensitive to ciprofloxacin and gentamicin $(100 \%$, each) followed by kanamycin $(94.7 \%)$ and was observed multidrug resistance $100 \%, 86.9 \%$ and $75 \%$ to streptomycin, penicillin, and erythromycin respectively. Streptococcus spp. isolates were most frequently resistant to penicillin and erythromycin (100\%,each) but high sensitive to gentamicin and oxytetracycline (100\%, each). Isolates of CoNS showed high susceptibility $100 \%$ to sulphamethoxazole-trimethoprim, ciprofloxacin, and gentamicin. Conversely, demonstrated a multidrug resistance against ampicillin $63.7 \%$ followed by novobiocin and neomycin $(54.6 \%$, each) and finally, 50\% resistance was recorded to penicillin, erythromycin, and amoxicillin-clavulanic acid. E.coli isolates showed 100\% sensitivity to oxytetracycline and neomycin.100\% of E.coli isolates showed multidrug resistance to(penicillin, ampicillin, and novobiocin). An antimicrobial sensitivity of Corynebacterium spp. was observed to gentamicin, kanamycin, cephalexin, and sulphamethoxazole-trimethoprim (100\%, each). Furthermore, 100\% of Corynebacterium spp. were resistant to ampicillin and penicillin. In this study penicillin was the most resistant $(87.38 \%$ ) against nearly all isolated pathogens. However, gentamicin with sensitivity (98.94\%) followed by ciprofloxacin $(91.85 \%)$ is a good choice for future treatment of clinical mastitis in ewes in the study area.

The electrolytes imbalance occurred during clinical mastitis of ewes with discard the history of recent lambing as a factor influence this imbalance was illustrated in (Table 4). A statistically highly significant decrease of $\mathrm{Ca}, \mathrm{Na}, \mathrm{Cl}, \mathrm{K}$ and $\mathrm{P}$ levels $(\mathrm{P}<0.001)$ in clinically mastitic ewes in comparison with other two apparently healthy groups except for Ca was more decline than the apparently healthy with a recent history of lambing but not statistically significant. A non- 
Citation: Hend M. El Damaty and ElShaima M. Fawzi, 2018. Clinical Mastitis in Sheep Smallholder System in Sharkia Province: Bacteriological Studies, In Vitro Antibiogram Profile and Mineral Picture. Advances in Environmental Biology., 12(4): 6-11.

significant decline in Zn level during clinical mastitis in comparison with the other 2 groups. Meanwhile, Mg level was not altered during the disease when compared with other 2 apparently healthy groups. From this study, the minerals imbalance are largely related to the occurrence of clinical mastitis or may be considered as a factor influence the incidence of the disease.

Fig. 1: (A, B) Gangrenous mastitis in a ewe.(C,D) Acute staphylococcus mastitis in a ewe

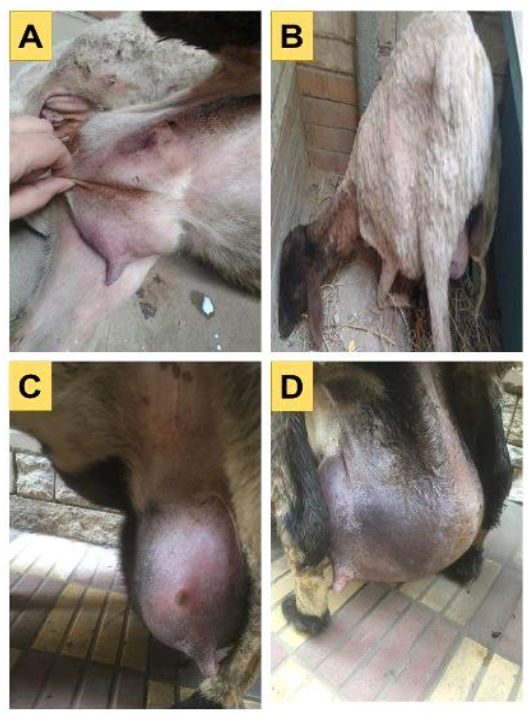

Table 1: Single and mixed bacterial isolates of dairy ewes clinically mastitic glands

\begin{tabular}{|c|c|c|c|c|c|c|}
\hline \multirow[t]{2}{*}{ *Isolated microorganisms } & \multicolumn{2}{|c|}{$\begin{array}{l}\text { Clinical mastitis } \\
\text { No. }=(160)\end{array}$} & Single isolates & $\%$ & Mixed isolates & $\%$ \\
\hline & No. & $\%$ & No. & $\%$ & No. & $\%$ \\
\hline S. aureus & 76 & 47.5 & 60 & 37.5 & 16 & 10 \\
\hline CoNS & 22 & 13.7 & 17 & 10.6 & 5 & 3.1 \\
\hline E. coli & 19 & 11.9 & 11 & 6.9 & 8 & 5 \\
\hline Corynebacterium spp & 13 & 8.1 & 4 & 2.5 & 9 & 5.6 \\
\hline Str. agalactiae & 11 & 6.9 & 9 & 5.6 & 2 & 1.3 \\
\hline Str. uberis & 4 & 2.5 & 3 & 1.9 & 1 & 0.6 \\
\hline Negative isolation & 15 & 9.4 & 0 & 0 & 0 & 0 \\
\hline Total & 160 & 100 & 104 & 65 & 41 & 25.6 \\
\hline
\end{tabular}

Table 2: Sensitivity and resistance profile of bacterial isolates in this study

\begin{tabular}{|c|c|c|c|c|c|c|c|c|c|c|c|c|}
\hline \multirow[t]{2}{*}{ Antibiotics } & \multicolumn{2}{|c|}{$\begin{array}{r}\text { S.aureus } \\
(76)\end{array}$} & \multicolumn{2}{|c|}{$\begin{array}{l}\text { CoNS } \\
(22) \\
\end{array}$} & \multicolumn{2}{|c|}{ E.coli (19) } & \multicolumn{2}{|c|}{$\begin{array}{l}\text { Corynebaterium } \\
\text { spp.(13) }\end{array}$} & \multicolumn{2}{|c|}{$\begin{array}{l}\text { Streptococcus } \\
\text { spp.(15) }\end{array}$} & \multicolumn{2}{|l|}{ Mean } \\
\hline & $\mathrm{S} \%$ & $\mathrm{R} \%$ & $\mathrm{~S} \%$ & $\mathrm{R} \%$ & $\mathrm{~S} \%$ & $\mathrm{R} \%$ & $\mathrm{~S} \%$ & $\mathrm{R} \%$ & $\mathrm{~S} \%$ & $\mathrm{R} \%$ & $\mathrm{~S} \%$ & $\mathrm{R} \%$ \\
\hline $\begin{array}{c}\text { Penicillin } \\
\text { (10 IU/disk) }\end{array}$ & 13.1 & 86.9 & 50 & 50 & 0 & 100 & 0 & 100 & 0 & 100 & $12.62^{\mathrm{f}}$ & $87.38^{\mathrm{a}}$ \\
\hline $\begin{array}{l}\text { Ampicilin } \\
(10 \mu \mathrm{g} / \text { disk })\end{array}$ & 27.6 & 72.4 & 36.3 & 63.7 & 0 & 100 & 0 & 100 & 26.6 & 73.4 & $18.10^{\mathrm{f}}$ & $81.90^{\mathrm{a}}$ \\
\hline $\begin{array}{l}\text { Oxytetracycline } \\
(30 \mu \mathrm{g} / \text { disk })\end{array}$ & 85.5 & 14.5 & 77.2 & 22.8 & 100 & 0 & 84.6 & 15.4 & 100 & 0 & $89.46^{\mathrm{ab}}$ & $10.54^{\mathrm{ef}}$ \\
\hline Streptomycin $(10 \mu \mathrm{g})$ & 0 & 100 & 81.8 & 18.2 & 42.1 & 57.9 & 76.9 & 23.1 & 73.3 & 26.7 & $54.82^{\text {cde }}$ & $45.18^{\mathrm{bcd}}$ \\
\hline Cephalexin $(30 \mu \mathrm{g})$ & 85.5 & 14.5 & 86.3 & 13.7 & 42.1 & 57.9 & 100 & 0 & 53.3 & 46.7 & $73.44^{\text {abc }}$ & $26.56^{\text {def }}$ \\
\hline $\begin{array}{l}\text { Amoxicillin + clavulanic } \\
\text { acid }(20 / 10 \mu \mathrm{g})\end{array}$ & 52.6 & 47.4 & 50 & 50 & 63.1 & 36.9 & 76.9 & 23.1 & 66.6 & 33.4 & $61.84^{\text {bcd }}$ & $38.16^{\text {cde }}$ \\
\hline $\begin{array}{l}\text { Erythromycin } \\
(15 \mu \mathrm{g} / \text { disk })\end{array}$ & 25 & 75 & 50 & 50 & 52.6 & 47.4 & 38.4 & 61.6 & 0 & 100 & $33.20^{\mathrm{ef}}$ & $66.80^{\mathrm{ab}}$ \\
\hline $\begin{array}{l}\text { Sulphamethoxazole- } \\
\text { trimethoprim } \\
(23.75 / 1.25 \mu \mathrm{g})\end{array}$ & 89.4 & 10.6 & 100 & 0 & 73.6 & 26.4 & 100 & 0 & 60 & 40 & $84.60^{\mathrm{ab}}$ & $15.40^{\mathrm{ef}}$ \\
\hline Neomycin $(30 \mu \mathrm{g})$ & 72.3 & 27.7 & 45.4 & 54.6 & 100 & 0 & 61.5 & 38.5 & 73.3 & 26.7 & $70.50^{\mathrm{abc}}$ & $29.50^{\text {def }}$ \\
\hline Kanamycin $(30 \mu \mathrm{g})$ & 94.7 & 5.3 & 63.6 & 36.4 & 78.9 & 21.1 & 100 & 0 & 66.6 & 33.4 & $80.76^{\mathrm{abc}}$ & $19.24^{\text {def }}$ \\
\hline Novobiocin $(20 \mu \mathrm{g})$ & 64.4 & 35.6 & 45.4 & 54.6 & 0 & 100 & 69.2 & 30.8 & 20 & 80 & $39.80^{\operatorname{def}}$ & $60.20^{\mathrm{abc}}$ \\
\hline Ciprofloxacin $(5 \mu \mathrm{g} /)$ & 100 & 0 & 100 & 0 & 94.7 & 5.3 & 84.6 & 15.4 & 80 & 20 & $91.85^{\mathrm{a}}$ & $8.14^{\mathrm{f}}$ \\
\hline $\begin{array}{l}\text { Chloramphenicol } \\
(30 \mu \mathrm{g} / \text { disk })\end{array}$ & 59.2 & 40.8 & 95.4 & 4.6 & 89.4 & 10.6 & 92.3 & 7.7 & 53.3 & 46.7 & $77.92^{\mathrm{abc}}$ & $22.08^{\text {def }}$ \\
\hline $\operatorname{Gentamicin}(10 \mu \mathrm{g} / \text { disk })^{\prime}$ & 100 & 0 & 100 & 0 & 94.7 & 5.3 & 100 & 0 & 100 & 0 & $98.94^{\mathrm{a}}$ & $1.06^{\mathrm{f}}$ \\
\hline
\end{tabular}

$\mathrm{S}$, sensitive; R, resistant; Means followed by the same letter are not significantly different based on Duncan test at $\mathrm{p} \leq 0.05$. 
Citation: Hend M. El Damaty and ElShaima M. Fawzi, 2018. Clinical Mastitis in Sheep Smallholder System in Sharkia Province: Bacteriological Studies, In Vitro Antibiogram Profile and Mineral Picture. Advances in Environmental Biology., 12(4): 6-11.

Table 3: Analysis of variance for fourteen antibiotics sensitivity and resistance

\begin{tabular}{|l|l|l|l|l|}
\hline Source of variation & DF & SS & MSS & F ratio \\
\hline Antibiotics & 13 & 50203.91 & 3861.83 & 9.738 \\
\hline Error & 56 & 22208.71 & 396.58 & \\
\hline Total & 69 & 72412.62 & & \\
\hline
\end{tabular}

Table 4: Determination of mineral picture in clinically mastitic ewes and apparently healthy ones in serum

\begin{tabular}{|l|l|l|l|l|}
\hline Parameters & $\begin{array}{l}\text { Apparently normal ewes } \\
\text { without a history of recent } \\
\text { lambing }\end{array}$ & $\begin{array}{l}\text { Apparently normal } \\
\text { recently lambing ewes }\end{array}$ & Clinically mastitic ewes & P value \\
\hline Calcium $(\mathrm{Ca}) \mathrm{mg} / \mathrm{dl}$ & $10 \pm 0.7^{\mathrm{a}}$ & $8 \pm 0.6^{\mathrm{bc}}$ & $7 \pm 0.2^{\mathrm{c}}$ & 0.001 \\
\hline $\begin{array}{l}\text { Magnesium }(\mathrm{Mg}) \\
\mathrm{mg} / \mathrm{dl}\end{array}$ & $2 \pm 0.8$ & $2 \pm 0.6$ & $2 \pm 0.3$ & 1.00 \\
\hline Sodium $(\mathrm{Na}) \mathrm{mmol} / \mathrm{l}$ & $151 \pm 0.9^{\mathrm{a}}$ & $150 \pm 0.8^{\mathrm{a}}$ & $147 \pm 0.3^{\mathrm{b}}$ & 0.001 \\
\hline $\begin{array}{l}\text { Potassium }(\mathrm{K}) \\
\mathrm{mmol} / \mathrm{l}\end{array}$ & $5.2 \pm 0.16^{\mathrm{a}}$ & $5.1 \pm 0.3^{\mathrm{a}}$ & $4.3 \pm 0.1^{\mathrm{b}}$ & 0.005 \\
\hline $\begin{array}{l}\text { Phosphorus (P) } \\
\text { mg/dl }\end{array}$ & $7.3 \pm 0.1^{\mathrm{a}}$ & $7.1 \pm 0.2^{\mathrm{a}}$ & $6.5 \pm 0.3^{\mathrm{b}}$ & 0.004 \\
\hline $\begin{array}{l}\text { Chloride }(\mathrm{Cl}) \\
\mathrm{mmol} / \mathrm{l}\end{array}$ & $110 \pm 0.3^{\mathrm{a}}$ & $111 \pm 0.3^{\mathrm{a}}$ & $101 \pm 0.8^{\mathrm{b}}$ & 0.000 \\
\hline $\mathrm{Zinc}(\mathrm{Zn}) \mu \mathrm{g} / \mathrm{dl}$ & $1.13 \pm 0.2$ & $0.99 \pm 0.7$ & $0.98 \pm 0.6$ & 0.976 \\
\hline
\end{tabular}

Means \pm SE followed by the same letter are not significantly different based on one way ANOVA at $\mathrm{p} \leq 0.05$.

\section{DISCUSSION}

Mastitis is one of the most common health problems that can cause economic losses in sheep with worldwide distribution including Egypt. Knowledge and identification of bacteria causing mastitis in dairy ewes would possibly facilitate ways for reducing the infection. In the present study S.aureus (47.5\%), Streptococcus spp. (9.4\%) and E.coli (11.9\%), were the main etiological agents of mastitis in ewes ,the same was mentioned by [25, 36, 6]. The most implicated pathogen in all infected halves was S.aureus with prevalence rate $47.5 \%$ either alone or in mixed infected samples. This result was in line with a study reported by $[42,11]$ who confirmed that S.aureus is the most incriminated pathogen in clinical mastitis of ewes. [16,43] stated that S.aureus was responsible for just about $40 \%$ of cases of clinical mastitis in ewes suckling lambs and approximately $80 \%$ of cases in dairy ewes. The high prevalence of S.aureus may be due to poor milking hygiene as it is mainly spread during milking via milkers hands this coincides with the previous findings of [14]. CoNS were considered as one of the main pathogens of clinical mastitis in ewes with prevalence rate $13.7 \%$. This result was in line with a study reported by [39, 2,41]. S.aureus and CoNS are the organisms most usually associated with clinical mastitis [4,48]. During this study, E. coli was isolated from $11.9 \%$ of clinically ewes mastitic milk samples and nearly the same percentage was reported by [3]. This low incidence might be due to the lower diffusion of Gram-negative bacteria in sheep than in cattle, where E.coli is considered a major pathogen causing mastitis in cattle [50]. No bacteria isolated in 15(9.4\%) samples from such cases, nearly an equivalent percent was mentioned by [46]. This might be related to the infection caused by bacteria other than the isolated ones or due to yeast, fungus or even mycoplasma species infections.

The in vitro susceptibility test of bacterial isolates showed the greatest resistance to penicillin $(87.38 \%)$, this could be associated with its greater use because smallholder sheep production is carried in a more extensive way in producing milk and meat in Egypt and this may be interpreted the resistance of isolated bacteria to it. The results are consistent with the previous findings by [1]. S.aureus was highly sensitive to gentamicin, ciprofloxacin (100\%, each) and second most extremely effective drugs were kanamycin $(94.7 \%)$ followed by sulphamethoxazole-trimethoprim $(89.4 \%$.). At the same time isolates of S.aureus were found to be more resistant to penicillin $(86.9 \%)$ and ampicillin $(72.4 \%)$ and this resistance may be due to plasmid-encoded penicillinase enzyme (beta-lactamase) which tolerate beta-lactam antibiotics. This is like to that recorded by [36]. Isolates of CoNS showed high susceptibility $100 \%$ to sulphamethoxazole-trimethoprim, ciprofloxacin and gentamicin meanwhile $63.7 \%$ was the resistance against ampicillin, $50 \%$ resistance was recorded to penicillin and amoxicillin-clavulanic acid respectively. Relatively, similar results were ascertained previously in Egypt by [20] who reported that S.aureus was highly sensitive to oxytetracyclin100\%, gentamicin $80 \%$ and resistant to penicillin $60 \%$ and CoNS was highly sensitive to gentamicin $100 \%$, oxytetracycline $89.2 \%$ and resistant to penicillin $67.6 \%$ and amoxicillin-clavulanic acid $35.1 \%$. E.coli was observed as highly sensitive to neomycin and tetracycline (100\%, each). While second most highly effective drugs demonstrated were gentamicin, ciprofloxacin (94.7\%, each) followed by chloramphenicol 89.4\%. Our results are not in agreement with [34] who reported (0\%) $E$. coli sensitivity to gentamicin, kanamycin, and chloramphenicol respectively and weak sensitivity for tetracycline (16.66\%). Corynebacterium spp were $100 \%$ sensitive to gentamicin, kanamycin, cephalexin, and sulphamethoxazole-trimethoprim and conversely, the resistance to ampicillin and penicillin (100\%, each). The resistance may be due to the synthesis of penicillinase enzymes and alteration of penicillin-binding proteins [27]. So regional characterization of microorganisms should be done.

The electrolyte difference is usually measured in case of subclinical mastitis and mostly in cattle but few studies are conducted to evaluate the minerals imbalance in clinical mastitis especially in ewes. Hypocalcemia detected in this paper was in line with many studies [ 35,$12 ; 21,57,45]$. This hypocalcemia may be related to partial anorexia and emaciation of clinically mastitic ewes. The decrease of levels of $\mathrm{Na}, \mathrm{K}$ and $\mathrm{Cl}$ levels in the clinically mastitic group compared with healthy ones were in accordance with [5] but in contrary to [21]. The decline of serum phosphorus level may be due to increase secretion of this element in milk due to damage of udder wall in addition to the phosphorus element play a major role in metabolism energy in the body for the building of ATP [8], this result was in line with $[18,21,51]$

$\mathrm{Mg}$ level was not altered in case of clinical mastitis of ewes, this result was in agree with [18,57] suggesting this element may be not correlated with the occurrence of clinical mastitis. Our result is contrary to [52] who detected a high level of serum $\mathrm{Mg}$ in acute mastitic buffalo meanwhile decline the level of this element was detected by $[21,51]$.

A slight decrease of $\mathrm{Zn}$ level in the clinically mastitic group but not significant, the same was detected by [22,44]. Nearly, $\mathrm{Zn}$ element was not altered in case of clinical mastitis in cow [57]. On the other hand, significant decline level of $\mathrm{Zn}$ in case of $E$. coli induced mastitis [40]. In spite of disturbance of this element in milk due to mastitis that also leads to decrease milk production yield so the serum level change appears later [23]. The exact role of $\mathrm{Zn}$ in clinical mastitis was not clear, but the result of [53] thought the importance of this element for formation of keratin of teat canal and reduce IMIs so the supplementation of $\mathrm{Zn}$ in ration lead to reduce the incidence of subclinical mastitis in the cow.

This imbalance may be attributed to bacterial infection of udder which leads to increase vascular permeability so increase leak in milk resulted in the change of milk components [55] or bacterial infection produced endotoxin which affects on endogenous mediators lead to minerals imbalance. The difference of minerals concentration between different studies may be related to mastitic stage in each animal, the animal species and breed use in different investigations . In contrary to our study, detection of serum electrolytes levels including $\mathrm{Ca}, \mathrm{K}, \mathrm{Na}, \mathrm{Mg}$ and $\mathrm{Cl}$ in Awassi sheep affected with clinical and subclinical mastitis caused by S.aureus were in the normal limits [32]. 


\section{CONCLUSIONS}

The diagnosis of mastitis in ewes is similar to that for cattle and other farm animals. However, we reported a high prevalence of the disease among ewes raised under the traditional house owners breeding system suggesting the necessity for additional economical management measures under this production system. In this context, $S$. aureus is taken into account as a serious inflammation pathogen incriminated in ewes clinical mastitis. Monitoring of the antimicrobial profile is necessary due to the increased microbial resistance and for choice of the effective antibiotic. Penicillin was the most resistant (87.38\%) against nearly all isolated pathogens. However, gentamicin with sensitivity $(98.94 \%)$ followed by ciprofloxacin $(91.85 \%)$ is a good choice for treatment of ewes clinical mastitis in the study area. Calcium, $\mathrm{Na}, \mathrm{Cl}, \mathrm{K}$, and phosphorus levels are most essential elements subjected to a disturbance in serum in association with such disease so its supplementation along with treatment may facilitate the rapid recovery.

\section{ACKNOWLEDGMENTS}

Credit to the sheep household breeders for their interest in scientific research and making their ewes available for our study. This work was done on the author's expense without funding from any organization. Necessary facilities of the Animal Medicine Department, Faculty of Veterinary Medicine, Zagazig University were used.

\section{REFERENCES}

[1] Aires-de-Sousa, M., C.E. Parente, O. Vieira-da-Motta, I.C. Bonna, D.A. Silva and H. deLencastre, 2007. Characterization of Staphylococcus aureus " isolates from buffalo, bovine, ovine, and caprine milk samples collected in Rio de Janeiro State, Brazil. Appl Environ Microbiol., 73(12): 3845-3849. HYPERLINK "https://www.ncbi.nlm.nih.gov/pubmed/17449696

[2] Albenzio, M., L. Taibi, A. Muscio and A. Sevi, 2002. Prevalence and etiology of subclinical mastitis in intensively managed flocks and related changes in the yield and quality of ewe milk. Small Ruminant Research, 43: 219-226.

[3] 52Alharbi, K.B., 2014. Detection of Antimicrobial Resistance of Staphylococcus aureus isolates at Qassim Region central of Saudi Arabia. International Journal of Food, Agriculture and Veterinary Sciences, 4(1): 81-92.

[4] Arsenault, J., P. Dubreuil, R. Higgins and D. Belanger, 2008. Risk factors and impacts of clinical and subclinical mastitis in commercial meat-producing sheep flocks in Quebec, Canada. Prev. Vet. Med., 87: 373-393.

[5] Atroshi, F., J. Parantainen, S. Sankari, M. Jarvinen, L.A. Lindberg and H. Saloniemi, 1996. Changes in inflammation related blood constituents of mastitic cows. Veterinary Research, 27: 125-132.

[6] Azmi, D.H., O. Maher, S.A. Saddam, I.A. Hala, A.A. Amal, S.O. Sharaf, M.Q. Issam, M.A. Hanee and E. Jafar,2014. Prevalence of mastitis pathogens and their resistance against antimicrobial agents in Awassi sheep in AL-Balqa Province of Jordan. American Journal of Animal and Veterinary Sciences, 9 (2): 116-121.

[7] Barber, S., J. Allen, P. Mansell and G. Browning, 2006. Mastitis in the ewe. In: Proceedings of the Australian Sheep Veterinarians 2006 Conferences, Australian Sheep Veterinarians Wagga Wagga and Hobart, pp: 127-132.

[8] Basiri, M.S., S.A. Sridhari and K. Rakesh, 2009. Subclinical mastitis in buffaloes: Investigations on oxidative stress. Haryana Vet., 48: 47-48.

[9] Behrens, H., M. Ganter and T. Hiepe, 2001. Mastitis. In: Behrens H, Ganter M, Hiepe T Lehrbuch der Schafkrankheiten. Berlin: Parey, pp: 87-92.

[10] Bergonier, D. and X. Berthelot, 2003. New advances in epizootiology and control of ewe mastitis. Livest Prod Sci., 79: 1-16.

[11] Bergonier, D., R. De Cremoux, R. Rupp, G. Lagriffoul and X. Berthelot, 2003. Mastitis of dairy small ruminants. Veterinary Res., 34: 689-716.

[12] Bertoni, G., E. Trevisi, F.P. Cappelli, V. Cappa, F. Piccioli and F. Trenti, 1994. Variation in blood parameters with mastitis of different severity in dairy cows. Proceedings 18th World Buiatrics Congress: 26th Congress of the Italian Association of Buiatrics, Bologna, Italy, 2: 1427-1430.

[13] Bianchi, L., A. Bolla, E. Budelli, A. Caroli, C. Casoli, M. Pauselli and E. Duranti, 2004. Effect of udder health status and lactation phase on the characteristics of Sardinian ewe milk. J. Dairy Sci., 87: 2401-2408.

[14] Bradley, A.J., 2002. Bovine mastitis: An evolving disease. Vet. J. 164: 116-128.

[15] Clinical and Laboratory Standards Institute (CLSI), 2015. Methods for antimicrobial dilution and disk susceptibility testing of infrequently isolated or fastidious bacteria. 3rd Ed. CLSI guidelines M45, Wayne, USA, 35: 16-19.

[16] Contreras, A., D. Sierra, A. Sanchez, J.C. Corrales, J.C. Marco, M.J. Paape, C. Gonzalo, 2007. Mastitis in small ruminants. Small Rumin Res., 68: 145-153.

[17] Dore, S.M., S. Liciardi, S. Amatiste, G. Bergagna, V. Bolzoni, A. Caligiuri, G. Cerrone, C.O. Farina, M.A. Montagna, M.L. Saletti, G. Scatassa, Sotgiu and E.A. Cannas, 2016. Survey on small ruminant bacterial mastitis in Italy, 2013-2014. Small Rumin. Res., 141: 91-93.

[18] Dwivedi, H.P., M. Kumar and A.K. Upadhyay, 2004. Biochemical changes in cows suffering from mastitis. Indian Journal of Veterinary Medicine, 24: 101102.

[19] EFSA, 2015. Scientific opinion on the welfare risks related to the farming of sheep for wool, meat and milk production. European Food Safety Authority (EFSA), Parma, Italy Rev 18 version 22-09-2014.

[20] El Khabaz, K.A.S., S.S. Malek and H.A. Hussein, 2015. Bacteriological, cytological and hematological changes associated the ovine subclinical mastitis. Assiut Veterinary Medicine Journal, 61(145): 236-241.

[21] El-Zubeir, I.E.M., O.A.O. ElOwni and G.E. Mohamed, 2005. Effect of mastitis on macro-minerals of bovine milk and blood serum in Sudan. J. S. Afr. vet. Ass. 76(1): 22-25.

[22] El-Zubeir, I.E.M., O.A.O. ElOwni and G.E. Mohamed, 2006. Effect of mastitis on trace elements of milk and blood serum in Friesian dairy cows. Asian J. of Animal and Veterinary Advances, 1(1): 82-85.

[23] Erskine, R.J. and P.C. Bartlett, 1993. Serum concentrations of copper, ,ron and zinc during Escherichia coli-induced mastitis. J. Dairy Sci., 76: 408-413.

[24] Finegold, S.M. and W.J. Martin, 1982. Bailey and scott's Diagnostic Microbiology. 6th Ed., The C.V. Mosby Company, St. Louis, Torento, London.

[25] Fthenakis, G.C and J.E.T. Jones, 1990. The effect of inoculation of coagulase-negative staphylococci into the ovine mammary gland. J Comp Pathol., 102: 211-219.

[26] Fthenakis, G.C., 1994. Prevalence and etiology of subclinical mastitis in ewes of Southern Greece. Small Rumin. Res., 13: 293-300.

[27] Garcia-Bravo, M., J.M. Aguado, J.M. Morales and A.R. Noriega,1996. Influence of external factors in resistance of Corynebacterium urealyticum to antimicrobial agents. Antimicrob Agents Chemother., 40(2): 497-499.

[28] Giadinis, N.D., G. Arsenos, P. Tsakos, V. Psychas, C.I. Dovas, E. Papadopoulos, H. Karatzias and G.C. Fthenakis, 2012. Milk-drop syndrome of ewes: Investigation of the causes in dairy sheep in Greece. Small Ruminant Research, 106(1): 33-35.

[29] Gonzalo, C., C. Ariznabarreta, J.A. Carriedo and F. San Primitivo, 2002. Mammary pathogens and their relationship to somatic cell count and milk yield losses in dairy ewes. J. Dairy Sci., 85: 1460-1467.

[30] Gonzalo, C., J.A. Tardaguila, L.F. De la Fuente and F. San Primitivo, 2004. Effects of selective and complete dry therapy on prevalence of intramammary infection and on milk yield in the subsequent lactation in dairy ewes. J. Dairy Res., 71: 33-38.

[31] Hariharan, H., W. Donachie, C. Macaldowie and G. Keefe, 2004. Bacteriology and somatic cell counts in milk samples from ewes on a Scottish farm. Can. J. Vet. Res., 68: 188-192.

[32] Ismail, Z.B. and M.O. Alekish, 2015. Hematology and serum biochemistry analyses in Awassi sheep affected with clinical and subclinical mastitis caused by Staphylococcus aureus and antimicrobial sensitivity patterns of the isolated bacterial strains. Animal Biology and Animal Husbandry J. 7(2): 202-207.

[33] Jaeggi, J.J., S. Govindasamy-Lucey, Y.M. Berger, M.E. Johnson, B.C. Mckusick, D.L. Thomas and W.L. Wendorff, 2003. Hard ewe's milk cheese manufactured from milk of three different groups of somatic cell counts. J. Dairy Sci., 86: 3082-3089.

[34] Kalhoro, D.H., N. Rahu, M.S. Kalhoro, T. Hussain, A. Kaka, M. Tariq and S.A. Pirzado, 2016. Antimicrobial sensitivity of bacterial species isolated from subclinical mastitis in sheep. Sci.Int. (Lahore), 28(5): 4793-4798. 
[35] Katholm, J. and H.P. Andersen, 1992. Acute coliform mastitis in dairy cows: endotoxin and biochemical changes in plasma and colony-forming units in milk. Vet. Rec., 131: 513-514.

[36] Lafi, S.Q. and N.Q. Hailat, 1998. Incidence and antibiotic sensitivity of bacteria causing bovine and ovine clinical mastitis in Jordan. Pak. Vet. J., 18: 88-94.

[37] Lafi, S.Q., A.M.Al-Majali, M.D. Rousan and J.M. Alawneh,1998. Epidemiological studies of clinical and subclinical ovine mastitis in Awassi sheep in northern Jordan. Prev. Vet. Med., 33: 171-181.

[38] Larsgard, A.G. and A. Vaabenoe, 1993. Genetic and environmental causes of variation in mastitis in sheep. Small Rumin Res., 12: 339-347.

[39] Las Heras, A., L. Dominguez and J.F. Fernandez- Garayzabal, 1999. Prevalence and etiology of subclinical mastitis in dairy ewes of the Madrid region. Small Ruminant Res., 32: 21-29.

[40] Lohuis, J.A.C., Y.H. Schukken, J.H.M. Verheijden, A. Brand and A.S.J. Van Miert, 1990. Effect of severity of systemic signs during the acute phase of experimentally induced Escherichia coli mastitis on milk production losses. J. Dairy Sci., 73: 333-341.

[41] Marogna, M., S. Rolesu, S. Lollai, S. Tola and G. Leori, 2010. Clinical findings in sheep farms affected by recurrent bacterial mastitis. Small Rumin. Res., 88: $119-125$.

[42] Mavrogenis, A.P., A. Koumas, C.K. Kakoyiannis and C.H. Taliotis, 1995. Use of somatic cell counts for the detection of subclinical mastitis in sheep. Small Ruminant Research, 17: 79-84.

[43] Menzies, P.I. and S.Z. Ramanoon, 2001. Mastitis of sheep and goats. Vet. Clin. North. Am. Food. Anim. Pract. 17: 333-48.

[44] Mobarak, M.G., M.A.M. El-Beahwey, A.A. Maarouf and Y.M. Abd El-Raof, 2007. Correlation between cattle mastitis and serum iron, zinc and copper, The Second Scientific Conference, Fac. Vet. Med., Benha University Benha - Ras Sedr 25-28: 234-246.

[45] Mohamed, T., S.M. Gouda, and M.M. Bahnass, 2015. Clinical and laboratory findings of clinical mastitis in Holstein- Friesian dairy cattle. Zag. Vet. J. 43(2): 160-171.

[46] Mørk, T., S. Waage, T. Tollersrud, B. Kvitle and S. Svil, 2007. Clinical mastitis in ewes; bacteriology, epidemiology and clinical features. Acta Veterinaria Scandinavica, 49: 23.

[47] Oliver, S.P., J.S. Hogan, B.M. Jayarao and W.E. Owens, 2004. Microbiological procedures for the diagnosis of bovine udder infection and determination of milk quality. [NMC, publication, 2004]. Verona (WI): National Mastitis Council. $4^{\text {th }}$ ed. p: 47.

[48] Omaleki, L., S.R. Barber, J.L. Allen and G.F. Browning, 2010. Mannheimia species associated with ovine mastitis. J. Clin. Microbiol., 48: $3419-3422$.

[49] Quinn, P.J., M.E. Carter, B. Markey and G.R. Carter, 1994. Clinical Veterinary Microbiology. 1st Ed. Wolfe Publishing, London, ISBN-13: 978-0-72341711-8, pp: 684 .

[50] Quinn, P.J. and B.K. Markey, 2003. Concise Review of Veterinary Microbiology. Blackwell Publishing Ltd, The Atrium, Southern Gate, Chichester, West Sussex, PO19 8SQ, Oxford, UK.

[51] Siddiqe, Z.F., S. Islam, S.S. Islam, S. Islam, S. Islam and B.C. Das, 2015. Haematobiochemical changes in subclinical mastitis affected high yielding dairy cows in Chittagong district. International Journal of Natural and Social Sciences, 2: 30-34.

[52] Singh, H., 1999. Electrolyte and mineral status in buffaloes at different stages of lactation and clinical mastitis. MVSc Thesis submitted to Punjab Agricultural University, Ludhiana, Punjab, India.

[53] Spain, J.N., C.A. Jones, C.J. Rapp, M.T. Socha and D.J. Tomlinson, 2005. The effect of complexed zinc on keratin synthesis in the teat canal and the establishment and severity of experimentally induced E. coli mastitis in dairy cows. in: H. Hogeveen (Ed.) Mastitis in Dairy Production. Current Knowledge and Future Solutions. Wageningen Academic Publ., Wageningen, the Netherlands, p: 948.

[54] Spanu, C., Y.M. Berger, D.L. Thomas and P.L. Ruegg, 2011. Impact of intramammary antimicrobial dry treatment and teat sanitation on somatic cell count and intramammary infection in dairy ewes. Small Ruminant Research, 97: 139-145.

[55] Sutra, L. and B. Poutrel, 1994. Virulence factors involved in the pathogenesis of bovine intramammary infections due to Staphylococcus aureus. J. Med. Microbiol., 40: 79-89.

[56] Windria, S., D.C. Widianingrum and S.I.O. Salasia, 2016. Identification of Staphylococcus aureus and Coagulase Negative Staphylococci isolates from Mastitis Milk of Etawa Crossbred Goat. Research Journal of Microbiology, 11(1): 11.

[57] Yildiz, H. and E. Kaygusuzolu, 2005. Investigation of $\mathrm{Ca}, \mathrm{Zn}, \mathrm{Mg}$, Fe and $\mathrm{Cu}$ concentrations in blood and milk of cows with negative and positive CMT results. Bulletin of the Veterinary Institute in Pulawy, 49: 209-213. 